\title{
IMPLEMENTASI ALGORITMA FAST FOURIER TRANSFORM PADA MONITOR GETARAN UNTUK ANALISIS KESEHATAN JEMBATAN
}

\author{
Ahmad Fatah ${ }^{1}$, Uung Ungkawa ${ }^{2}$, Mira Musrini Barmawi ${ }^{3}$ \\ 1,2,3 Jurusan Teknik Informatika, Fakultas Teknologi Industri, Institut Teknologi Nasional Bandung \\ Jalan PH.H. Mustofa No.23, Bandung \\ 1ahmadfattah058@gmail.com
}

\begin{abstract}
ABSTRAK
Jembatan merupakan bagian yang penting dalam suatu sistem jaringan jalan, karena pengaruhnya yang signifikan bila jembatan itu runtuh atau tidak berfungsi dengan baik, maka keruntuhan jembatan akan mengganggu kelancaran transportasi orang dan barang. Sistem monitor dikembangkan untuk dapat mengetahui kondisi struktur jembatan agar dapat mengantisipasi kegagalan struktur. Dimana dari hasil monitor ini akan dihasilkan data ferekuensi alami, tekanan beban dan lendutan. Data akselerasi Sumbu x,y,dan z akan diolah dengan algoritma Fast Fourier Transform (FFT), kemudian data ferekuensi yang telah diolah akan menghasilkan ferekuensi alami jembatan. Dari hasil penelitian menunjukkan bahwa monitoring getaran jembatan dapat ditampilkan dengan data akselerasi sumbu $\mathrm{X}, \mathrm{Y}$ dan $\mathrm{Z}$ maupun FFT. Dengan beban $6 \mathrm{~kg}$ didapat akselerasi Sumbu $\mathrm{x}=1.29, \mathrm{Y}=0.73$ dan $\mathrm{Z}=$ 13.39, Ferkunesi Dasar $X=1.82, Y=1.03$ dan $Z=18.93$. Untuk parameter lendutan dengan akurasi $99.66 \%$, dengan beban $6 \mathrm{Kg}$ didapat Rata-rata error sebesar $11 \mathrm{~mm}$ (millimeter) dengan rata-rata persentase error sebesar $0.0396 \%$. untuk parameter Teakann berat dengan akurasi 99,534\%, dengan beban $6 \mathrm{~kg}$ didapat Rata-rata persentasi error sebesar $0.1821 \mathrm{Kg}$ dengan persentase error tertinggi sebesar $0.4566 \%$. Kesimpulan yang didapatkan dari hasil penilitian bahwa setiap sensor untuk mengitung parameter kesehatan pada purwarupa Jembatan dengan bentang $65 \mathrm{~cm}$ dari aspek getaran tergolong pada nilai kondisi baik dengan nilai getaran 1,82 Hz. Ditinjau dari aspek lendutandengan beban muatan $6 \mathrm{~kg}$, jembatan tidak baik, karena memiliki rata-rata lendutan adalah $10 \mathrm{~mm}$ atau 1 $\mathrm{cm}$, dengan batas maksimal $0,65 \mathrm{~cm}$.
\end{abstract}

Kata Kunci: fast fourier transform (FFT); Frekuensi Alami; Structural Health Monitoring System (SHMS); tekanan beban

\section{PENDAHULUAN}

Jembatan merupakan bagian yang penting dalam suatu sistem jaringan jalan, karena pengaruhnya yang signifikan bila jembatan itu runtuh atau tidak berfungsi dengan baik, maka keruntuhan jembatan akan mengganggu kelancaran transportasi orang dan barang.

Penetuan kelayakan atau kesehatan jembatan meliputi beberapa percobaan lapangan dan laboratorium termasuk uji sifatsifat bahan bangunan, uji kekuatan tarik, uji tekan, uji getaran dan uji kelelahan. Penurunan kesehatan dari Jembatan tidak dapat dihindarkan yang disebabkan oleh factor lingkungan seperti gempa, pengoperasian yang tidak memadai, penuaan, dan kerusakan yang disebabkan oleh manusia yang dapat mengancam keamanan dari fungsi jembatan itu sendiri [7].
Metode untuk mendeteksi kerusakan struktur menggunakan parameter getaran, tekanan dan lendutan. Pengujian getaran melengkapi pemeriksaan frekuensi getaran. Semakin tinggi tingkat kerusakan jembatan maka semakin besar getaran yang dihasilkan sehingga dapat mengganggu kinerja jembatan.

Maka diperlukan suatu sistem monitor getaran beban pada suatu jembatan. Semua pengukuran parameter kesehatan jembatan akan dilakukan pada pemodelan jembatan Dimana dari hasil pemantauan ini akan dihasilkan data getaran, tekanan beban dan lendutan. Data getaran ini kemudian akan diolah dengan algoritma Fast Fourier Transform (FFT), kemudian data ferekuensi yang telah diolah akan menghasilkan data getaran alami jembatan itu sendiri. Dengan demikian, sistem ini diharapkan dapat digunakan sebagai salah satu sarana 
penunjang pemeliharaan infrastruktur jembatan dan dapat mempermudah para engineer sipil untuk menganalisisnya keusakan jembatan.

\section{METODE PENELITIAN}

Sistem ini dibangun menggunakan metode penelitian Purwarupa (prototipe) yang digunakan sebagai cara untuk melakukan proses penelitian dengan tahapan yang akan dilakukan pada penelitian ini yaitu melakukan perancangan sistem yang meliputi kebutuhan hardware yang akan digunakan dalam pembangunan sistem, melakukan pengemasan sistem seperti pemasangan dan perangkaian semua komponen hardware utama seperti NodeMcu sebagai mikrokontroler (pengendali rangkaian), dari pemantauan getaran jembatan adalah mengidentifikasi gejala kerusakan di kondisi terkini berdasarkan tanda-tanda vibrasi ketika dilalui oleh beban kendaraan melalui identifikasi pergeseran frekuensi alamiahnya yang dihasilkan dari waktu ke waktu menggunakan sensor Accelerometer.

Data-data yang dideteksi sensor disimpan pada database menggunakan teknik IOT
(Internet Of Thing) yaitu aplikasi middleware yang dibuat dari pemrograman berbasis $P H P$ dengan memanfaatkan fungsi GET. Perhitungan nilai struktur yang diperlukan dalam analisis kesehatan jembatan pada parameter getaran, tekan beban dan lendutan. Nilai tersebut ditampilakan dalam sistem website.

\section{Pengumpulan Kebutuhan}

Kebutuhan secara keseluruhan dalam melaksanakan pembangunan sistem yaitu deskripsi kebutuhan alat, deskripsi kebutuhan perangkat lunak (software) dan deskripsi kebutuhan pendukung sistem.

\section{Desain Cepat}

Desain cepat membahas gambaran secara umum dari sistem monitor kesehatan struktur jembatan dengan menggunakan beberapa sensor sebagai alat untuk membaca dari data akselerasi atau getaran, Induran dan tekanan, berikut ini merupakan quick design dari penelitian ini

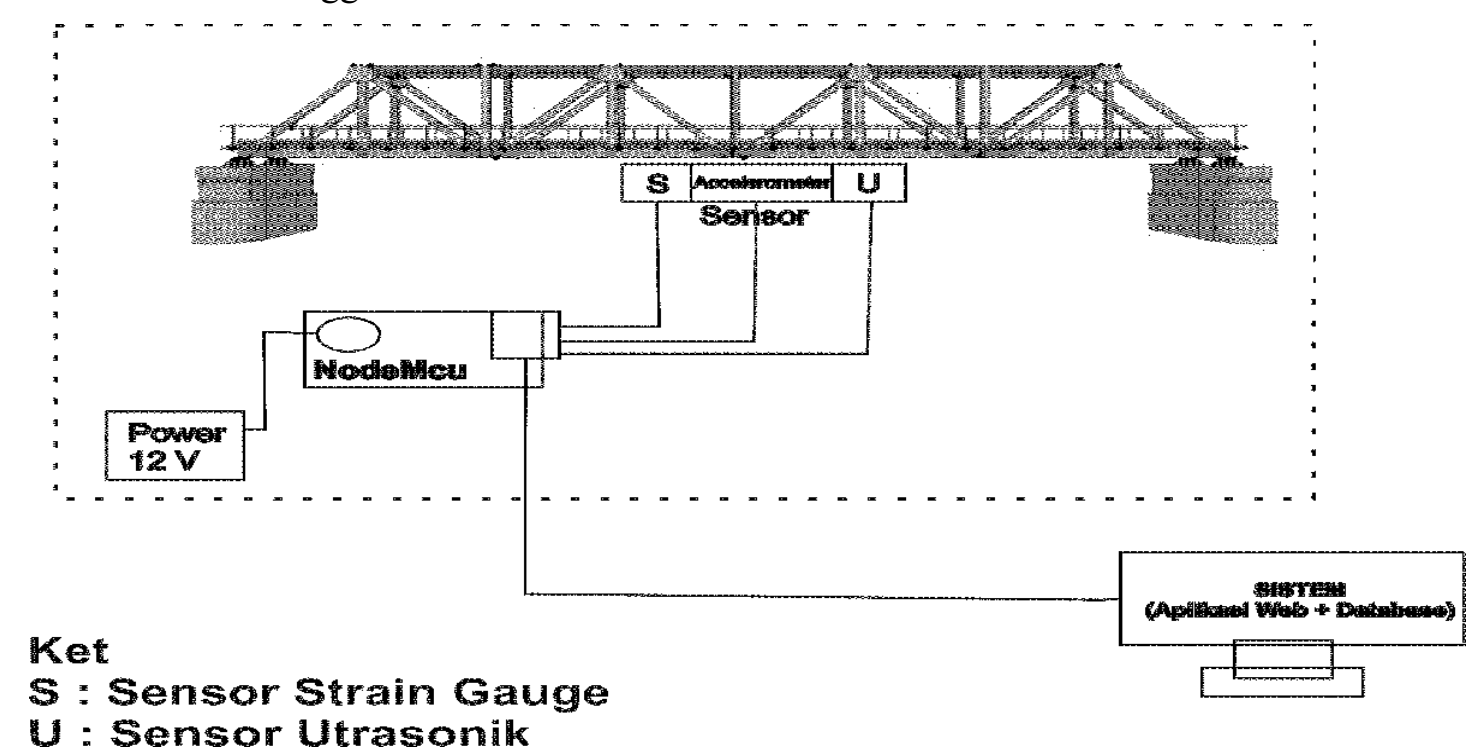

Gambar 1. Desain cepat

Dari skema desain cepat diatas sistem secara keseluruhan terbagi atas dua bagian yaitu hardware dan software, sesuai dengan penomoran pada gambar penjelasannya adalah sebagai berikut :

a. Komponen sensor yang digunakan adalah sensor Accelerometer, sensor ultrasonic , dan Loadcell . Semua komponen hardware dipasang pada bagian bawah kontruksi atas jembatan. b. Kendaraan yang ada pada kontruksi atas jembatan akan menimbulkan suatu getaran, tekanan, dan lendutan.

c. Respon getaran, tekanan, dan lendutan akan direspon oleh setiap komponen sensor yang telah terpasang.

d. Senor accelerometer akan merespon getaran, sensor ultrasonic akan merespon lendutan, dan sensor loadcell akan merespon tekanan. 
e. Hasil respon itu akan disimpan sebagai nilai parameter pengujian kesehatan jembatan.

f. Untuk nilai getaran akan di analisis menggukana Fast Fourier Transform (FFT) agar dapat dirubah ke frekuensi dasar.

\section{Perancangan Komponen Hardware}

Semua komponen hadware dirakit dan dikoneksikan ke module NodeMcu sebagai mikrokontroller dari sistem ini, dimana gambaran rancangan interkoneksi hardware dapat dilihat pada Gambar 2 berikut

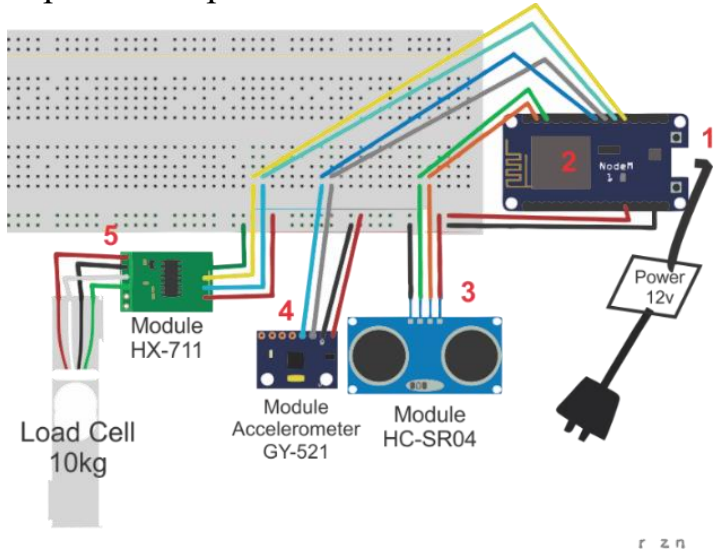

Gambar 2. Interkoneksi Hardware

Seperti yang terlihat pada Gambar dua. mengenai interkoneksi antar komponen hardware, akan dijelaskan berdasarkan penomoran pada gambar :

1. Merupakan aliran arus listrik dari adapter $12 \mathrm{~V}$ ke mikrokontroler NodeMcu.

2. Merupakan Esp8266 yang berfungsi untuk menghubungkan nodeMcu dengan sistem (aplikasi dan database) melaui jaaringan internet sebagai jalur komunikasi.

3. Merupakan koneksi antara module Ultrasonik yang berfungsi sebagai pembaca jarak dari lendutan yang dihubungkan ke NodeMcu. Pin Trig ultrasonik terhubung ke pin D1 pada NodeMCU, pin Echo ultrasonik terhubung ke pin D2 pada NodeMcu, pin GND ultrasonik terhubung ke pin GND NodeMcu, pin VCC ultrasonik terhubung $5 \mathrm{~V} \mathrm{NodeMcu.}$

4. Merupakan koneksi antara module Accelerometer yang berfungsi sebagai sebagai pembaca akselerasi nilai $\mathrm{x}, \mathrm{y}, \mathrm{dan} \mathrm{z}$ yang dihubungkan ke NodeMcu. Pin SCL Accelerometer terhubung ke pin D6 pada NodeMCU, pin SDA Accelerometer terhubung ke pin D5 pada NodeMcu, pin GND Accelerometer terhubung ke pin GND NodeMcu, pin VCC Accelerometer terhubung 5V NodeMcu.

5. Terdapat Module Loadcell yang berfungsi sebagai pembaca dari tekanan beban jembatan. Loadcell ini di hubungkan dengan NodeMcu melalui tiga pin yaitu, pin DOUT Loadcell terhubung dengan pin D7 pada NodeMcu, pin SCK Loadcell terhubung dengan pin D8 pada NodeMcu, pin GND Loadcell terhubung ke pin GND NodeMcu, pin VCC Loadcell terhubung 5V NodeMcu.

\section{Blok Diagram}

Blok diagram pada penelitian sistem monitor analisis kesehatan struktur jembatan, secara garis beasar sensor mendeteksi parameter-parameter yang diukur kemudian nilai bacaan sensor akan diproses pada mikrikontroler sehingga mendapatkan nilai yang diinginkan. Nilai hasil proses dari mikrokontroler akan ditmpilkn berupa grafik dan tabel, kemudian nilai tersebut akan dibandingkan dengan data perencanaan untuk mengetahui kondisi.
INPUT

PROSES

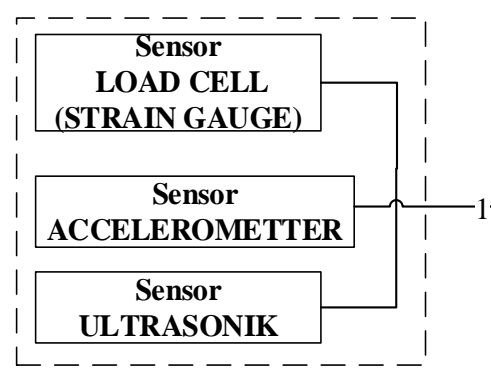

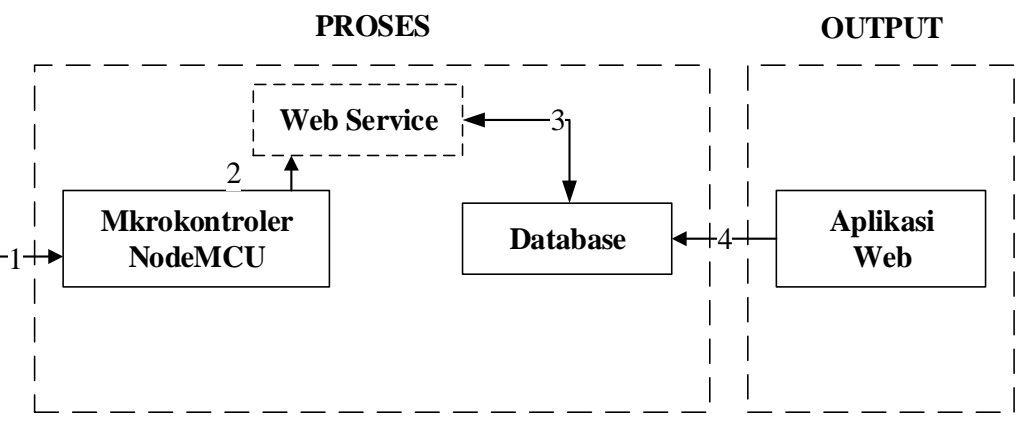

Gambar 3. Blok Diagram Sistem 
Berdasarkan Gambar tiga (3)., akan dijelaskan mengenai block diagram sistem sebagai berikut:

1. Sensor-sensor mendeteksi gejala pada struktur jembatan yaitu akselerasi, tekanan, dan panjang lendutan.

2. Kemudian nilai yang didapatkan dari sensor akan diproses oleh mikrokontroler nodeMCUuntuk diteruskan ke web service.

3. Web service sebagai perantari antara NodeMCU dan database.

4. Menmpilkan hasil nilai data sensor pada aplikasi Sistem informasi WEB. Data yang ditampilkan berupa grafik dan tabel dari masing-masing parameter yaitu lendutan, getaran atau akselerasi, dan tekannan.

\section{Diagram Alir Pengambilan Data Accelerometer}

Proses pengambilan data sensor pada tahap ini adalah inisialisasi akselerometer accelerometer, inisialisasi ini dilakukan pada listing kode pada Arduino IDE. Accelerometer akan medeteksi gejala yang ditimbulkan oleh struktur jembatan, akibat dari beban kendaraan yang ada pada atas jembatan.

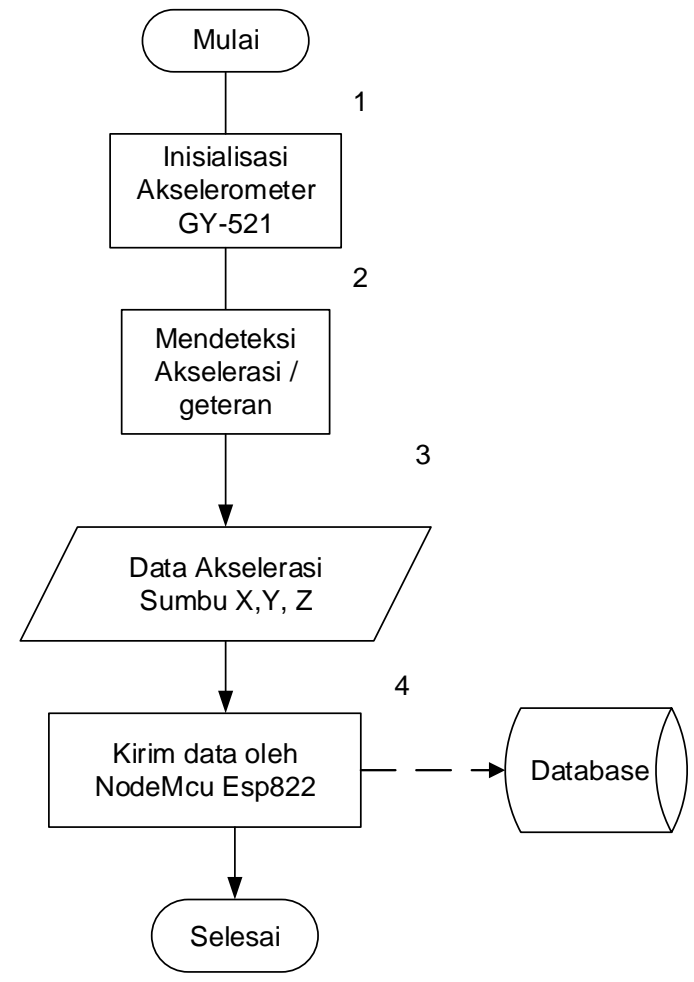

Gambar 4. Diagram Alir Pengambilan Data accelerometer
Format data yang diambil oleh akselerometer accelerometer adalah nilai sumbu X,Y,dan Z. modul nRF24101. Setelah data yang diambil mengeluarkan nilai dari sumbu $\mathrm{X}, \mathrm{Y}$ dan $\mathrm{Z}$, maka data akan dikirim menggunkan esp822 dan disimpan pada database sistem. Diagram alir pengambilan data dapat dilihat pada Gambar 4.

\section{Diagram Alir Pengambilan Data Ultrasonik}

Pada Gambar 5, Proses pengambilan data sensor pada tahap ini adalah deklarasikan terlebih dahulu sensor yang digunakan Ultrasonik ultrasonik, kemudian kita proses dengan memasukan rumus untuk menentukan jarak dengan skala milimeter. Setelah proses memasukan rumus benar maka data akan mengeluarkan nilai jarak yang dibaca sensor ultrasonik kemudian akan dikirim menggunakan NodeMCU Esp822.

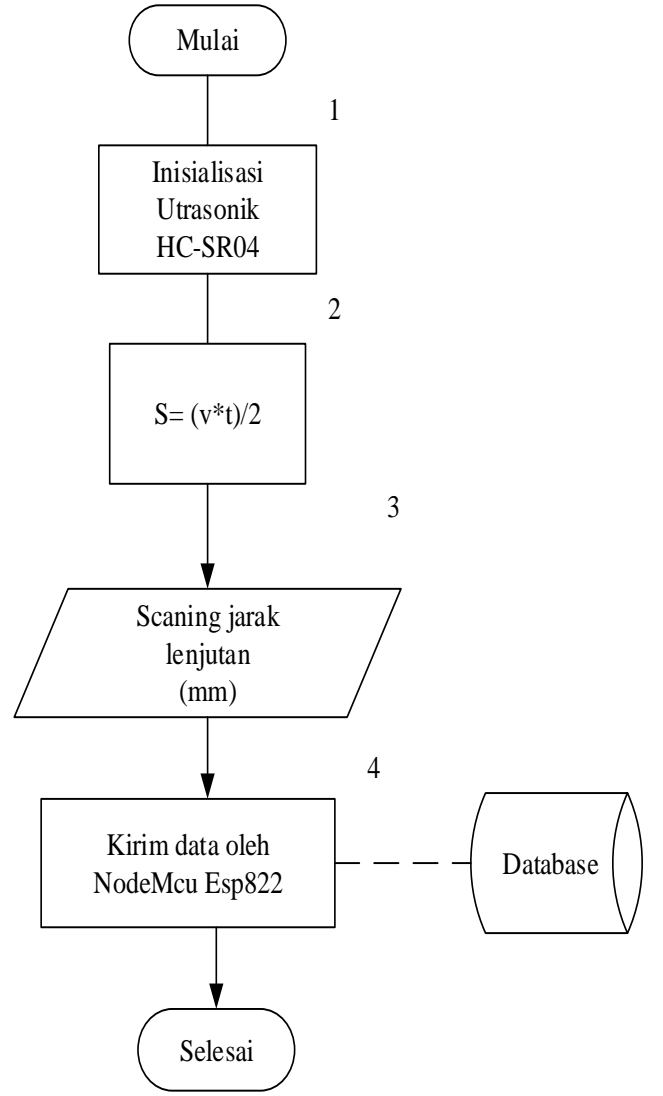

Gambar 5. Diagram Alir Pengambilan Data ultrasonik

Pengambilan jarak yang dilakukan oleh sensor Utrasonik ini adalah jarak lendutan yang dihasilkan dari gejala Struktur jembatan prototipe yang mendapatkan beban kendaraan. 


\section{Diagram Alir Pengambilan Data Loadcell}

Proses pengambilan data sensor pada tahap ini adalah deklarasikan terlebih dahulu sensor Load cell, kemudian sensor tersebut harus dikalibrasi dengan berat beban yang sudah diketahui sebagaib kalibrasi faktor. Setelah proses kalibrasi maka data akan mengeluarkan berat yang dibaca sensor Load cell kemudian akan dikirim menggunakan NodeMCU Esp822.

Berat yang dihitung oleh sensor Load cell adalah berat beban kendaraan yang sudah dikurangi dari berat strktur awal jembatan prototipe, seperti pada diagram alir pada Gambar 6.

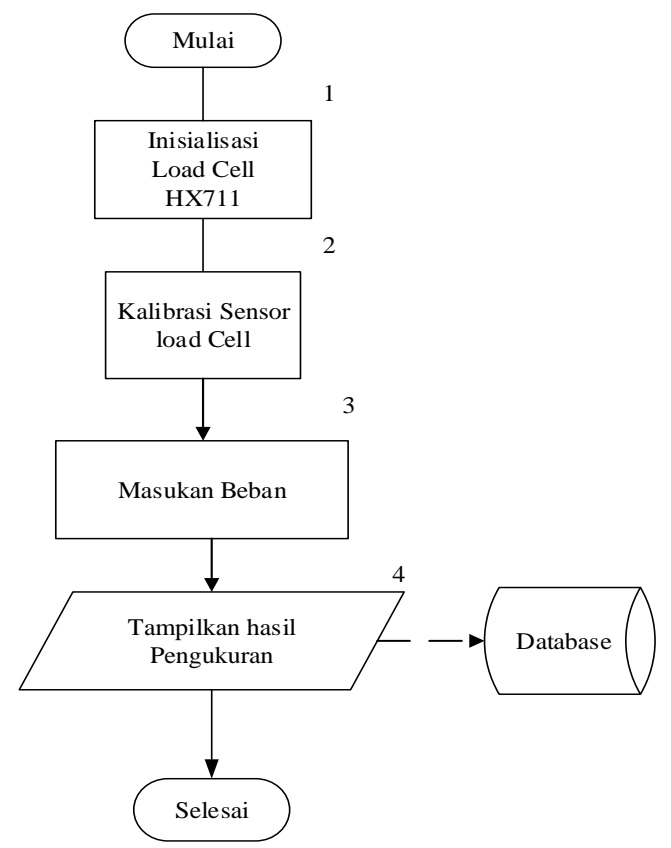

Gambar 6. Diagram Alir Pengambilan Data

\section{Load cell}

\section{HASIL DAN PEMBAHASAN}

\section{Fast Fourier Transform (FFT)}

Fast Fourier Transform (FFT) adalah metode yang sangat efisien untuk menghitung koefisien dari Fourier diskrit ke suatu finite sekuen dari data yang komplek. Karena substansi waktu yang tersimpan lebih dari pada metoda konvensional, fast fourier transform merupakan aplikasi temuan yang penting didalam sejumlah bidang yang berbeda seperti analisis spectrum, speech and optical signal processing, design filter digital.

Algoritma FFT berdasarkan atas prinsip pokok dekomposisi perhitungan discrete fourier transform dari suatu sekuen sepanjang $\mathrm{N}$ ke dalam transformasi diskrit Fourier secara berturut-turut lebih kecil.

$X[k]=\sum_{n=0}^{N-1} x[n], W_{N}^{n k} \quad ; k=0,1,2, \ldots, N-1$

Dimana $W_{N}^{n k}$ disebut sebagai twiddle factor, memiliki nilai $e^{-\frac{j 2 \pi n k}{N}}$, sehingga

$$
X[k]=\sum_{n=0}^{N-1} x[n], e^{-\frac{j 2 \pi n k}{N}} \quad ; k=0,1,2, \ldots, N-1
$$

\section{Implementasi}

Model purwarupa jembatan mempunyai panjang $65 \mathrm{~cm}$, lebar $40 \mathrm{~cm}$, dan tinggi $35 \mathrm{~cm}$ digunakan sebagai purwarupa jembatan peraga dimana tempat diletakkannya sensor.

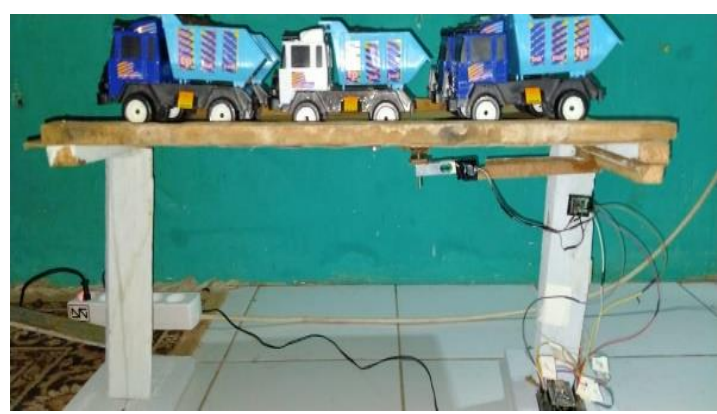

Gambar 7. Purwarupa Jembatan

\section{Pengujian lendutan Sensor ultrasonik}

Pengujian dilakukan dengan meletakkan sensor ultrasonik ULTRASONIK pada struktur atas jembatan yang dapat bergerak naik dan turun. Pengujian dilakukan dengan cara menggambil data dari lendutan purwarupa jembatan yang disimulasikan dengan sebuah beban 1 kendaraan mainan dengan berat $1 \mathrm{~kg}$ dengan berbagai variasi, 2 kendaraan mainan, 4 kendaraan mainan dan 6 kendaraan mainnan. Nilai yang didapat dari sensor akan dibandingkan dengan nilai referensi berupa penggaris.

Tabel 1. Pengujian akurasi sensor ultrasonik(tanpa beban)

\begin{tabular}{|r|r|r|r|}
\hline 气ี & $\begin{array}{l}\text { Ultrasonik } \\
\text { (Lendutan } \\
\text { Mm) }\end{array}$ & $\begin{array}{l}\text { Penggaris } \\
\text { dalam } \\
\text { (mm) }\end{array}$ & $\begin{array}{l}\text { Error } \\
\text { (MM) }\end{array}$ \\
\hline 1 & 300 & 310 & 10 \\
\hline 2 & 300 & 310 & 10 \\
\hline 3 & 300 & 310 & 10 \\
\hline 4 & 300 & 305 & 5 \\
\hline 5 & 300 & 305 & 5 \\
\hline
\end{tabular}




\begin{tabular}{|r|r|r|r|}
6 & 300 & 305 & 5 \\
\hline 7 & 300 & 305 & 5 \\
\hline 8 & 300 & 310 & 10 \\
\hline 9 & 300 & 310 & 10 \\
\hline 10 & 300 & 310 & 10 \\
\hline \multicolumn{3}{|c|}{ Rata-rata Error } & 8 \\
\hline
\end{tabular}

persen error $=$ [nilai eksperimental - nilai teoritis] / teoritis nilai x $100 \%$

Nilai eksperimental $=$ hasil dari sensor

Nilai teoritis $=$ nilai dari penggaris

Berdasarkan tabel 1 dari 10 data rekam didapatkan Rata-rata error sebesar $8 \mathrm{~mm}$ (millimeter) dengan rata-rata persentase error sebesar $0.0259 \%$. Sehingga didapat tingkat akurasi sebesar 99,699\%.

Tabel 2. Pengujian akurasi sensor ultrasonik $(6 \mathrm{Kg})$

\begin{tabular}{|c|c|c|c|}
\hline 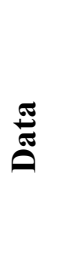 & $\begin{array}{l}\text { Utrasonik } \\
\text { (Lendutan } \\
\text { Milimeter) }\end{array}$ & 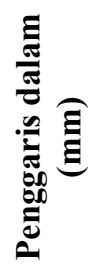 & Error (MM) \\
\hline 1 & 290 & 275 & 15 \\
\hline 2 & 290 & 270 & 20 \\
\hline 3 & 290 & 275 & 15 \\
\hline 4 & 290 & 280 & 10 \\
\hline 5 & 290 & 280 & 10 \\
\hline 6 & 290 & 280 & 10 \\
\hline 7 & 290 & 280 & 10 \\
\hline 8 & 290 & 285 & 5 \\
\hline 9 & 290 & 285 & 5 \\
\hline 10 & 290 & 280 & 10 \\
\hline \multicolumn{3}{|c|}{ Rata-rata Error } & 11 \\
\hline
\end{tabular}

persen error $=$ [nilai eksperimental - nilai teoritis] / teoritis nilai x $100 \%$

Nilai eksperimental $=$ hasil dari sensor

Nilai teoritis $=$ nilai dari penggaris

Berdasarkan tabel 2 dari 10 data rekam didapatkan Rata-rata error sebesar $11 \mathrm{~mm}$ (millimeter) dengan rata-rata persentase error sebesar $0.0396 \%$. Sehingga didapat tingkat akurasi sebesar $99,699 \%$.

Besarnya lendutan yang diizinkan terjadi pada jembatan didapat dari perhitungan berikut :
Bentang Jembatan (L) : $65 \mathrm{Cm}$

$$
\frac{1}{100} \times L
$$

Batas Maksimal lendutan adalah 0.65 CM.

Berdasarkan dari percobaan diatasan rata-rata lendutan adalah $1 \mathrm{~mm}$ atau $1,1 \mathrm{~cm}$, dengan batas maksimal $0,65 \mathrm{~cm}$ maka jembatan ini tidak baik.

\section{Pengujian Berat Tekanan Sensor LoadCell}

Pengujian dilakukan dengan meletakkan sensor Loadcell Hx711 pada struktur atas jembatan yang dapat bergerak naik dan turun. Pengujian dilakukan dengan cara menggambil data dari berat tekanan purwarupa jembatan yang disimulasikan dengan sebuah beban 1 kendaraan mainan dengan berat $1 \mathrm{~kg}$ dengan berbagai variasi,2 kendaraan mainan dan 6 kendaraan mainnan. Nilai yang didapat dari sensor akan dibandingkan dengan nilai berat kendaraan yang sudah di timbang dengan timbangan digital.

Tabel 3 Pengujian Prototipe Struktur Jembatan loadcell $(2 \mathrm{~kg})$

\begin{tabular}{|c|c|c|c|c|}
\hline ڤึ & 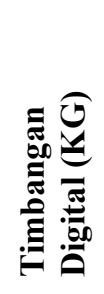 & $\begin{array}{c}\text { LoadCell } \\
\text { (Berat } \\
\text { Tekan } \\
\text { KG) }\end{array}$ & Error & 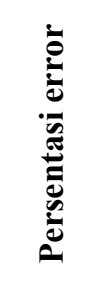 \\
\hline 1 & 2 & 0.8 & 1.2 & 1.5 \\
\hline 2 & 2 & 0.7 & 1.3 & 1.853 \\
\hline 3 & 2 & 0.9 & 1.1 & 1.222 \\
\hline 4 & 2 & 0.3 & 1.7 & 5.666 \\
\hline 5 & 2 & 0.63 & 1.37 & 2.174 \\
\hline 6 & 2 & 1.35 & 0.65 & 0.481 \\
\hline 7 & 2 & 1.79 & 0.21 & 0.117 \\
\hline 8 & 2 & 1.99 & 0.01 & 0.005 \\
\hline 9 & 2 & 2.14 & -0.14 & -0.065 \\
\hline 10 & 2 & 2.87 & -0.87 & -0.303 \\
\hline \multicolumn{4}{|c|}{ Rata-Rata } & 1.2655 \\
\hline \multicolumn{4}{|c|}{ Error tertinggi } & 5.666 \\
\hline
\end{tabular}

Berdasarkan tabel dari 10 data rekam didapatkan Rata-rata persentasi error sebesar $1.265 \mathrm{Kg}$ (Kilogram) dengan persentase error 
tertinggi sebesar 5.666\%. Sehingga didapat tingkat akurasi sebesar 94,334\%.

Tabel 4 Pengujian Prototipe Struktur Jembatan loadcell $(6 \mathrm{~kg})$

\begin{tabular}{|c|c|c|c|c|}
\hline 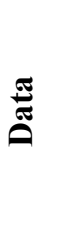 & 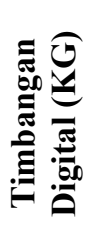 & $\begin{array}{c}\text { LoadCel } \\
\text { I(Berat } \\
\text { Tekan } \\
\text { KG) }\end{array}$ & $\begin{array}{l}\text { Error } \\
\text { Berat }\end{array}$ & 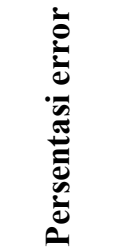 \\
\hline 1 & 6 & 3.26 & 2.74 & 0.45666 \\
\hline 2 & 6 & 4.18 & 1.82 & 0.30333 \\
\hline 3 & 6 & 4.75 & 1.25 & 0.20833 \\
\hline 4 & 6 & 4.18 & 1.82 & 0.30333 \\
\hline 5 & 6 & 4.75 & 1.25 & 0.20833 \\
\hline 6 & 6 & 5.19 & 0.81 & 0.135 \\
\hline 7 & 6 & 5.39 & 0.61 & 0.10166 \\
\hline 8 & 6 & 5.74 & 0.26 & 0.04333 \\
\hline 9 & 6 & 5.75 & 0.25 & 0.04166 \\
\hline 10 & 6 & 5.88 & 0.12 & 0.02 \\
\hline \multicolumn{4}{|c|}{ Rata-Rata } & 0.1821 \\
\hline \multicolumn{4}{|c|}{ Error tertinggi } & 0.4566 \\
\hline
\end{tabular}

Berdasarkan tabel dari 10 data rekam didapatkan Rata-rata persentasi error sebesar $0.1821 \mathrm{Kg}$ (Kilogram) dengan persentase error tertinggi sebesar $0.4566 \%$. Sehingga didapat tingkat akurasi sebesar $99,534 \%$.

\section{Pengujian Pengolahan akselerasi/ getaran dengan Sensor Accelerometer (2 Kg)}

Pengujian dilakukan dengan meletakkan sensor Accelerometer accelerometer pada struktur atas jembatan bagian bawah rangka pada setengah bentang panjang purwarupa jembatan. Pengujian dilakukan dengan cara menggambil data dari akselerasi purwarupa jembatan yang disimulasikan dengan sebuah beban 1 kendaraan mainan dengan berat $1 \mathrm{~kg}$ dengan berbagai variasi,2 kendaraan mainan dan 6 kendaraan mainnan. Hasil akselerasi yang dibaca oleh sensor accelerometer akan diolah menggunakan algoritma FFT sehingga didapat nilai pada domain frekuensinya. Nilai frekuensi ini mengintepretasikan nilai frekuensi natural yang terjadi.

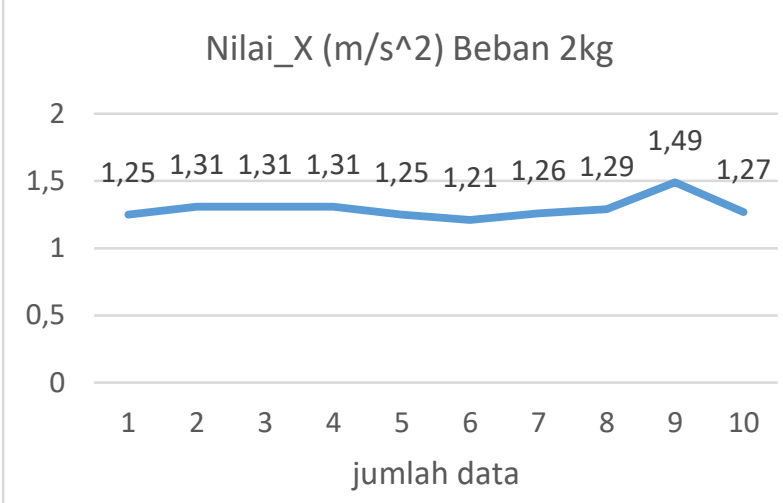

Gambar 7. Data Grafik Akselerasi Sumbu X

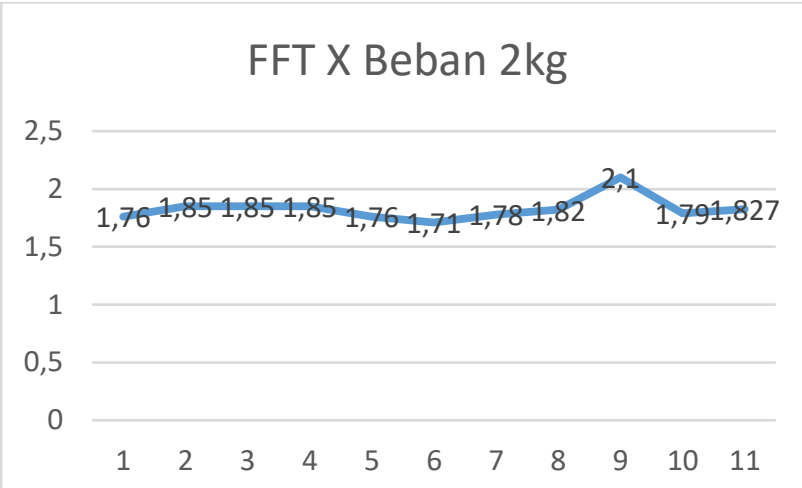

Gambar 8. Data Grafik Fast Fourier Transform

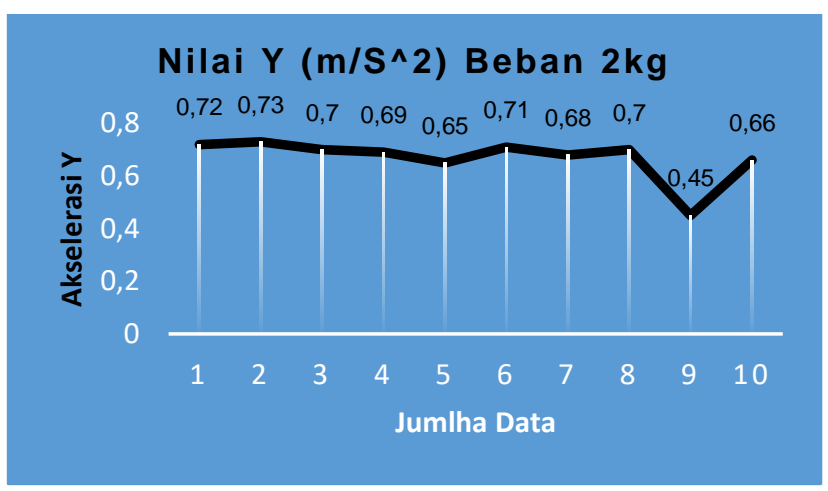

Gambar 9. Data Grafik Akselerasi Sumbu y

FFT Y Beban 2kg

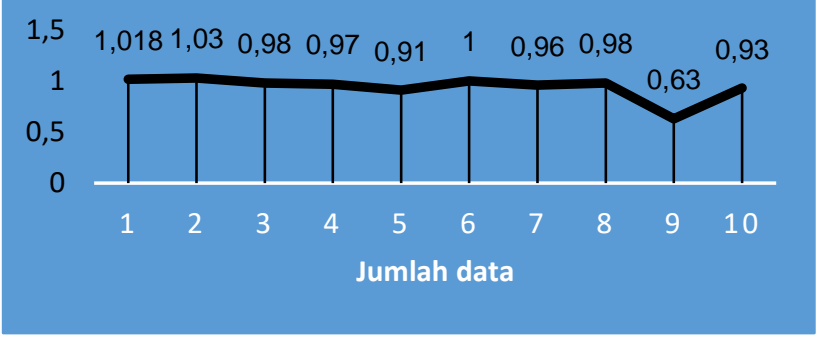

Gambar 10. Data Grafik Fast Fourier Transform 


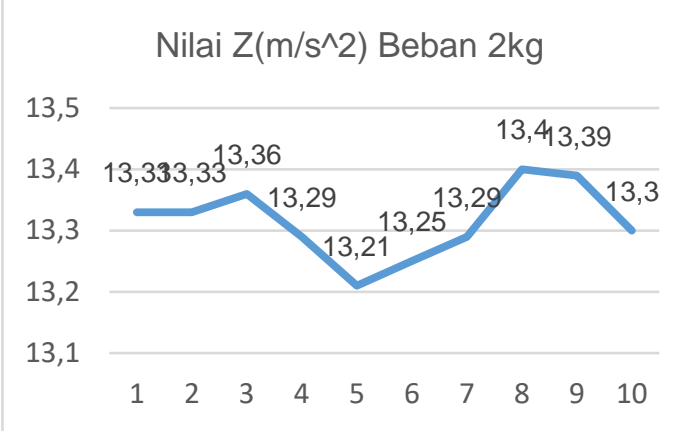

Gambar 11. Data Grafik Akselerasi Sumbu Z

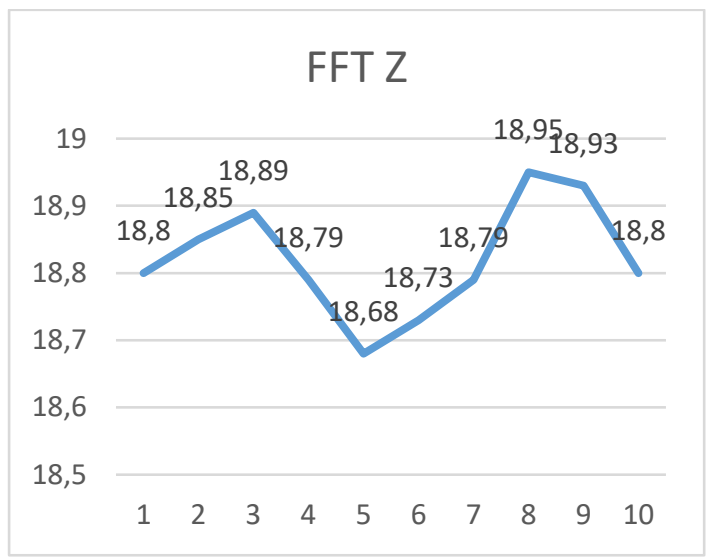

Gambar 12. Data Grafik Fast Fourier Transform

Berdasarkan pada pengujian dengan beban $2 \mathrm{~kg}$ didapatkan Nilai percepatan maksiman dari masing masih sumbu axis adalah

a. Sumbu $x=1.49$, Sumbu $Y=0.73$ dan sumbu $Z=13.4$

b. Ferkunesi Dasar $\mathrm{X}=2.1, \mathrm{Y}=1.03$ dan $\mathrm{Z}$ $=18.95$

\section{Pengujian Pengolahan akselerasi/ getaran dengan SensorAccelerometer (6KG)}

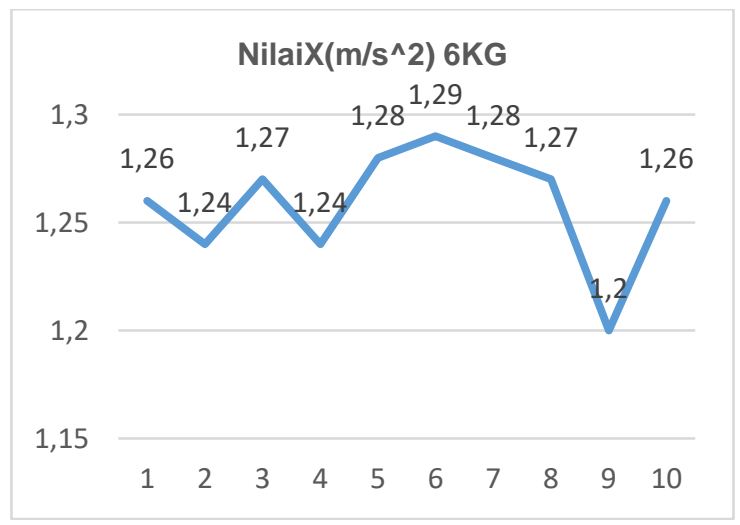

Gambar 13. Data Grafik Akselerasi Sumbu X

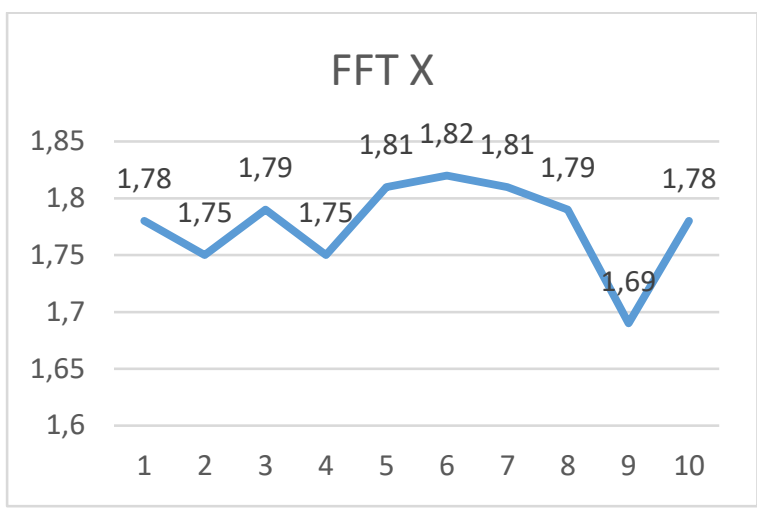

Gambar 14. Data Grafik Fast Fourier Transform

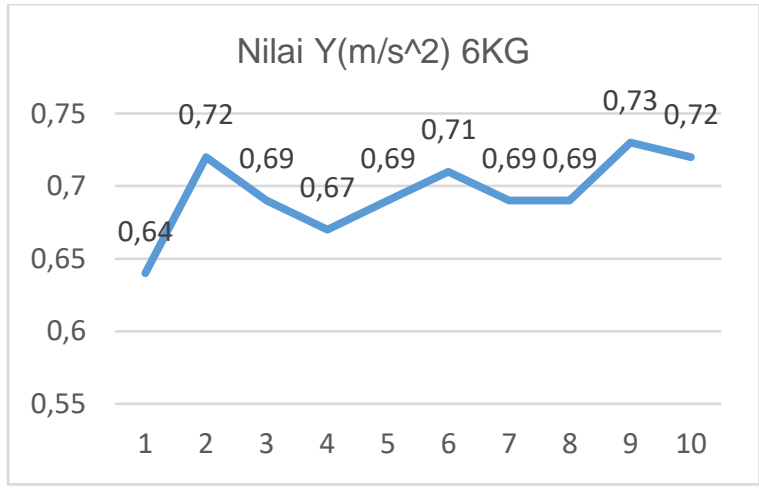

Gambar 15. Data Grafik Akselerasi Sumbu Y

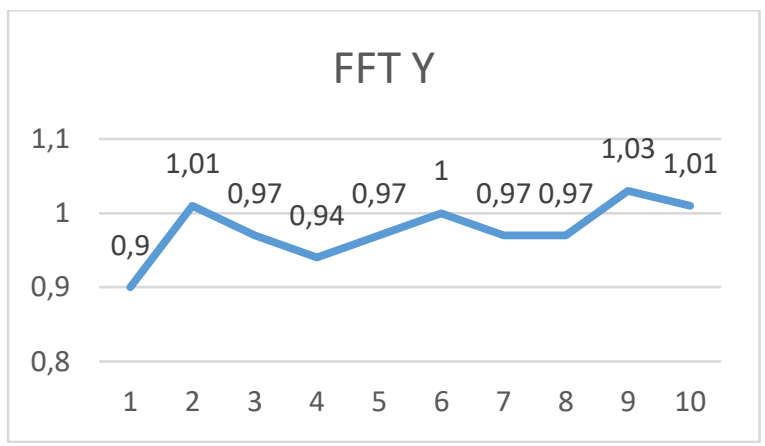

Gambar 16. Data Grafik Fast Fourier Transform

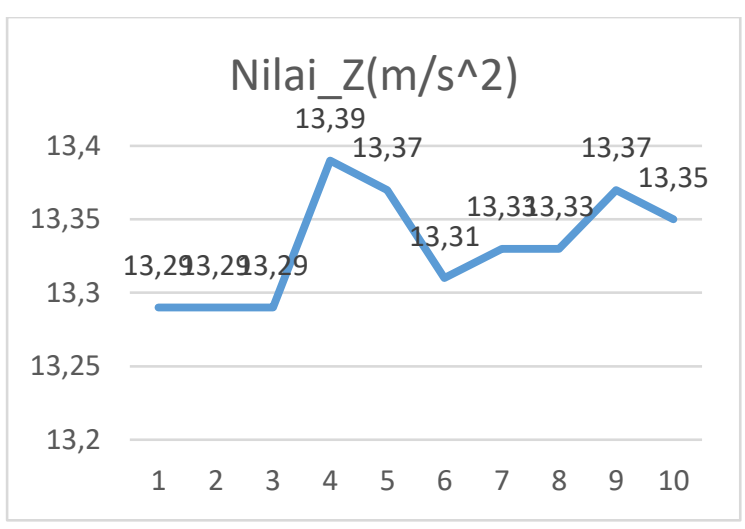

Gambar 17. Data Grafik Akselerasi Sumbu Z 


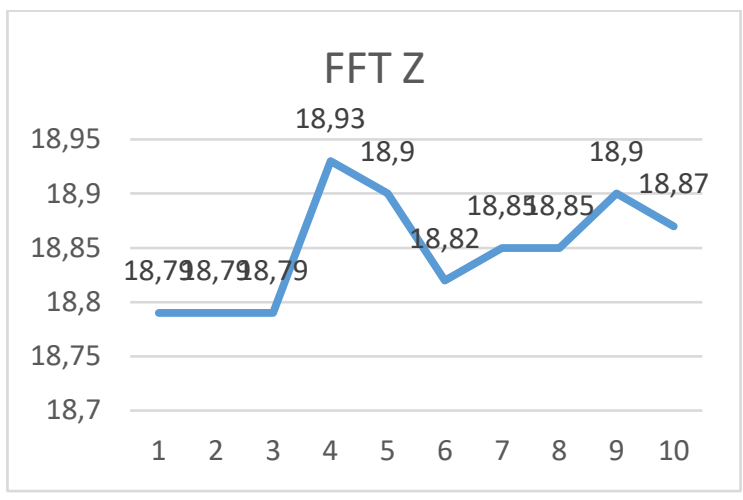

Gambar 18. Data Grafik Fast Fourier Transform

Berdasarkan pada pengujian dengan beban $6 \mathrm{~kg}$ didapatkan Nilai percepatan maksiman dari masing masih sumbu axis dan Frekuensi dasar sebagai berikut:

c. Sumbu $x=1.29$, Sumbu $Y=0.73$ dan sumbu $Z=13.39$

d. Ferkunesi Dasar $\mathrm{X}=1.82, \mathrm{Y}=1.03$ dan $\mathrm{Z}$ $=18.93$.

\section{KESIMPULAN}

Berdasarkan pengujian yang telah dilakukan dapat diambil kesimpulan sebagai berikut:

1. Akurasi dari pembacaan sensor ultrasonik untuk Lendutan sebesar 99,699\%, dangan penurunan sebesar $1 \mathrm{~cm}$.

2. Pada pemantauan getaran beban $2 \mathrm{Kg}$, nilai masing-masing frekuensi dasarnya adalah $\mathrm{X}=2.1 \mathrm{~Hz} . \mathrm{Y}=1.03 \mathrm{~Hz}$. $\mathrm{Z}=18.95 \mathrm{~Hz}$.

3. Pada pemantauan getaran beban $6 \mathrm{Kg}$, nilai frekuensi dasarnya adalah $X=1.82 \mathrm{~Hz}$. $Y=1.03 \mathrm{~Hz}$. $\mathrm{Z}=18.93 \mathrm{~Hz}$.

Kemampuan pada Jembatan bentang $65 \mathrm{~cm}$ dari aspek getaran, lendutan, adalah sebagai berikut: (Sumber: Manual Pemeliharaan Jembatan Pelengkung)

1. Ditinjau dari aspek getaran dengan beban muatan $6 \mathrm{~kg}$, tergolong pada nilai kondisi baik dengan nilai getaran $1,82 \mathrm{~Hz}$. Karena secara teoritis jembatan dengan bentang $60 \mathrm{~cm}$ memiliki batas maksimal $3.479 \mathrm{HZ}$ (Ardhi \& Utomo, 2015).

2. Ditinjau dari aspek lendutan dengan beban mutan 6KG, jembatan tidak baik. Karena berdasarkan dari percobaan diatasan rata-rata lendutan adalah $10 \mathrm{~mm}$ atau $1 \mathrm{~cm}$, dengan batas maksimal $0,65 \mathrm{~cm}$.

\section{DAFTAR PUSTAKA}

[1] Abdillah, M. (2019). RANCANG BANGUN SISTEM SENSOR STRAIN GAUGE ALAT PERCOBAAN REGANGAN DAN TEGANGAN BEAM DENGAN SISTEM AKUISISI DATA NATIONAL INSTRUMEN CDAQ 9172.

[2] Ardhi, S. a., \& Utomo, T. C. (2015). Analisis Kemampuan Layan Jembatan Rangka Baja Soekarno - Hatta Malang Ditinjau Dari Aspek Getaran, Lendutan Dan Usia Fatik.

[3] Azarya Putra, G., \& Ediansjah. (2016). IDENTIFIKASI MODAL PARAMETER STRUKTUR. Annual Civil Engineering Seminar.

[4] Huda, C., \& Purwandi, A. W. (2017). RANCANG BANGUNMONITORING GETARAN JEMBATAN RANGKA BAJA SOEKARNO-HATTA MALANG SEBAGAI PENILAIAN KONDISI BANGUNAN ATAS JEMBATAN MELALUI WEB. Jurnal JARTEL (ISSN (print): 2407-0807 ISSN (online): 24070807) Vol: 4, Nomor: 1.

[5] Imanningtyas, E., Akbar, S. R., \& Syauqy, D. (2017). Implementasi Wireless Sensor Network pada Pemantauan Kondisi Struktur Bangunan Menggunakan Sensor Accelerometer MMA7361. Jurnal Pengembangan Teknologi Informasi dan Ilmu Komputer.

[6] MIRZA A, M. I., \& Wibisono, W. (2017). Rancang Bangun Sistem Monitoring Struktur Bangunan Berbasis Jaringan Sensor Nirkabel dengan Analisis Nilai Modal Struktur (Studi Kasus Prototype Jembatan).

[7] Nababan , P. H. (2016). STRUCTURAL HEALTH MONITORING SYSTEM ALAT BANTU MEMPERTAHANKAN USIA TEKNIS JEMBATAN. Balai Besar Pelaksana Jalan Wilayah $V$.

[8] Nugraha, W., \& Sukmara , G. (2017). EVALUASI BEBAN LAYAN JEMBATAN APUNG PEJALAN KAKI TIPE PELENGKUNG RANGKA BAJA BERDASARKAN UJI PEMBEBANAN. Pusat Litbang Jalan dan Jembatan.

[9] Priatna, E. (2016). Pengembangan Sensor Vibrasi Menggunakan Accelerometer LIS3DSH Dengan Pemrosesan Data Secara Langsung di Dalam Mikrokontoler Mnggunakan Metode FFT.

[10] Putra, S. A., \& Sani, G. A. (2018). Sistem Penilaian Kondisi Jembatan Menggunakan Respons Dinamik dengan Wireless Sensor Network. JNTETI, Vol. 7, No. 3.

[11] Putra, Y. H., \& Aprianto, R. (2016). ALAT BANTU PENYANDANG TUNANETRA 
MENGGUNAKAN ULTRASONIK.

[12] Putri, A. E., \& Pranoto, Y. (2018). ANALISIS PERBANDINGAN STRUKTUR RANGKA BAJA BUKAKA DAN SNI DENGAN PEMODELAN TEKLA PADA JEMBATAN BETAPUS SAMARINDA. SNITT- Politeknik Negeri Balikpapan.

[13] Setiati, N. R., \& Surviyanto, A. (2013). ANALISIS UJI BEBAN KENDARAAN TERHADAP JEMBATAN INTEGRAL PENUH. Pusat Litbang Jalan dan Jembatan .

[14] Sujadi, H., \& Sopiandi, I. (2017). SISTEM PENGOLAHAN SUARA MENGGUNAKAN ALGORITMA FFT (FAST FOURIER TRANSFORM). ProsidingSINTAK.

[15] Tiffany, A., \& Bintoro Kusumo, B. P. (2019). Optimasi Dimensi Web Balok Gelagar I Terhadap Pembebanan Truk Pada Jalan Tol XYZ. Spirit of Civil Engineering (SPRING) Journal (ISSN: 2528-6234).
[16] Wardhana, F. N., \& Sumaryo, S. (2018). PEMANTAUAN STRUKTUR ATAS JEMBATAN. e-Proceeding of Engineering : Vol.5.

[17] Widyanto, S. A., \& Widodo, A. (2016). KARAKTERISTIK PEREDAMAN GETARAN KONSTRUKSI MODEL JEMBATAN UNTUK PENGEMBANGAN SISTEM DIGANOSIS POLA GAGAL.

[18] Wijaya, Andi; Suryanita, Reni. (2016). PREDIKSI RESPONS STRUKTUR JEMBATAN BETON PRATEGANG BERDASARKAN SPEKTRUM GEMPA INDONESIA DENGAN METODE JARINGAN SARAF TIRUAN. Jom FTEKNIK Volume 3 No.1.

[19] Wijayanto , A., \& Nasution , A. (2017). Evaluasi Integritas Sistem Struktur Jembatan Dr. Ir. Soekarno. JurnalTeoretis dan Terapan Bidang Rekayasa Sipil. 